\title{
A survey on impacts of bike-oriented policies on residents and economic activities
}

\author{
F. Pagliara \& L. Biggiero \\ Department of Civil, Architectural and Environmental Engineering, \\ University of Naples Federico II, Italy
}

\begin{abstract}
Fighting against the "car only" nature of towns, the bicycle has been gaining constant ground in the urban space since the 1970s. Much more than just a sport or leisure accessory, it has become a simple and efficient means of transport that, today, is an integral part of mobility services. The bicycle is ideal for short daily journeys, lends itself well to intermodality and is at the heart of sustainable development policy. For its user, it is practical, cheap, green and good for one's health; for the countries that have adopted it, developing cycleable infrastructures, it has almost always been successful. The success can be measured by the many impacts on residents and activities and it is related to a correct design of the bike network and services. A conflicting example can be considered the bike lane inaugurated on the 10th November 2012 in the city of Napoli (Italy). It was introduced without simulating it with a proper DSS in order to evaluate the possible impacts on the users or on non-users (externalities), like congestion, parking problems, impacts on the local economy and without first involving the stakeholders for their feedback before its realization. To analyse the effects of the bike lane on activities, residents and mobility choices, two different RP surveys have been carried out. A large part of respondents was sensitive to sustainable mobility and to the policy adopted by local authority. Both residents and retailers underlined the lack of parking spaces due to the bike lane and, as a consequence, a reduction of the turnover has been declared by retailers. Beneath bike mode is not considered nowadays as a valid alternative to car and public transport, a relevant increase in its use can be expected by surveys if right measures will be implemented.
\end{abstract}

Keywords: transportation, bike, retailer, impact. 


\section{Introduction}

Sustainability is about enabling all people to realize their potential within society, and improve their quality of life. The values recognized here include human potential, quality of life, equity, and justice. The ethical principle is that all people should be able to identify these values, including future generations [1].

Mobility to be sustainable should follow and adapt itself to the new needs of the society while avoiding disruptions in the societal, environmental and economic well-being that could offset the socio-economic benefits of accessibility improvement.

Fighting against the "car only" nature of towns, the bicycle has been gaining constant ground in the urban space since the 1970s. Much more than just a sport or leisure accessory, it has become a simple and efficient mean of transport that, today, is an integral part of mobility services. The bicycle is ideal for short daily journeys, lends itself well to intermodality and is at the heart of sustainable development policy. For its users, it is practical, cheap, green and good for one's health; for the countries that have adopted it, developing infrastructures suitable for cycling, it has almost always been successful (www.sustainable-mobility.org).

However, this passion for the bicycle knows no borders and is spreading across Europe as well as to the United States and Japan. Self-service rental bicycles, power-assisted bicycles, development of cycle paths, pedestrian-priority zones, secure bicycle parking and other services: more and more initiatives are reinforcing the bicycle's position in town and improving traffic and security.

Transit Oriented Development policies are well-known in the transport arena [2-4] but Bicycle Oriented Development (BOD) areas are becoming now more accepted. BOD, also known as BSD (Bicycle Supported Development), are "areas with attributes and features conducive to bicycling such as density of development and mix of uses, abundant and convenient bicycle parking, and proximity to cycling facilities" $[5,10]$.

Business establishments in these developments have a culture that accepts the bicycle mode, sometimes offering specials those who arrive by bike, together with amenities such as lockers and other services that are less obvious from the street. A wide range of impacts have been registered both on local economy and on residents. In this paper a case study will be analysed.

Traffic calming measures in general and bike lanes in particular, from the perspective of a small business owner, can bring several advantages, since they can increase residential and commercial property values, which attracts wealthier residents to the area and can increase retail sales and bring economic revitalization to a commercial corridor. Moreover they can create more attractive environments, increase safety for pedestrians, bicyclists, drivers, and other users of the street, which is good for business. These measures can encourage local residents to buy in their own neighborhoods, and also attract customers from a wider area due to reduced travel time and cost [7]. Improved transportation facilities can provide more convenience for employees. Traffic calming projects often require only minimal "down time" for construction, and most do not require any investment from business owners [6]. 
For this reason the bike is gaining positions in the ranking of the preferred transport modes all over the world. Both in the U.S. and Europe, where car is the dominant travel mode, many transport plans give a relevant role to biking motivating people to change their travel mode from car. Many are the studies and examples in literature focusing on the managing of bike sharing and bike traffic flows showing the various positive impacts of the safe biking on the area economy. Only few works focuses on the financial local impacts on retailers due to a new bike lane or how people perceive bike mode as suitable for their mobility. Some of this studies was generated in the U.S.A. which had in the last decades a relevant increase in the use of the bike mode due to the many new dedicated infrastructures. Indeed, in Portland, Oregon, a large survey on retailers was carried out after the implementation of a bike parking plan; it showed a general increase of customers both with a better living and a greater visibility of the stores. Retailers perceive bike lanes and bike parking areas an economic advantage. Indeed the results of a comparison between car and bike, reported in table 1, customers demonstrates the higher frequency of purchasing of the bike customer which leads to an increase of the total expense beneath the low budget dedicated to the single purchasing [10].

Table 1: Car and bike customers purchasing frequency and expense in Portland.

\begin{tabular}{|l|l|r|r|r|}
\hline Mode & Business & Trips/month & \$/trip & \$/month \\
\hline Car & Bar & 1.6 & 25.55 & 40.21 \\
\hline & Other & 9.9 & 7.98 & 79.37 \\
\hline & Restaurant & 2.2 & 18.74 & 41.16 \\
\hline & Total & 4.5 & 13.70 & 61.03 \\
\hline Bike & Bar & 4.9 & 14.08 & 68.56 \\
\hline & Other & 14.5 & 7.30 & 105.66 \\
\hline & Restaurant & 3.5 & 12.08 & 42.52 \\
\hline & Total & 7.1 & 10.66 & 75.66 \\
\hline
\end{tabular}

In Valencia Street, San Francisco, 66\% of retailers perceived an increase of their turnover due to the new built bike lane. In North Carolina, economic revenues due to the bike tourists has been estimated to be nine times the state expenditure for bike infrastructures [11].

\section{The case study of the bike lane in the city of Naples, Italy}

Italy is a great place for bicycles; indeed many famous bicycle racers came from Italy, and the Tour of Italy is one of only three bicycle tours in the world.

On the 10th November 2012 the first 16 kilometers of the bike lane were inaugurated in the city of Naples in the south of Italy (see Fig. 1). The new intervention was launched with a tour cycle of the mayor of Naples and the secretaries of the local authority. With a cost of 1 million Euro, provided by regional and local funds, the new intervention was conceived for linking the eastern to the western parts of the city. Cyclists could use some lines of public transport (funiculars and metro 6) carrying their bikes on trains without any additional ticket during a definite periods of time (www.comune.napoli.it). 


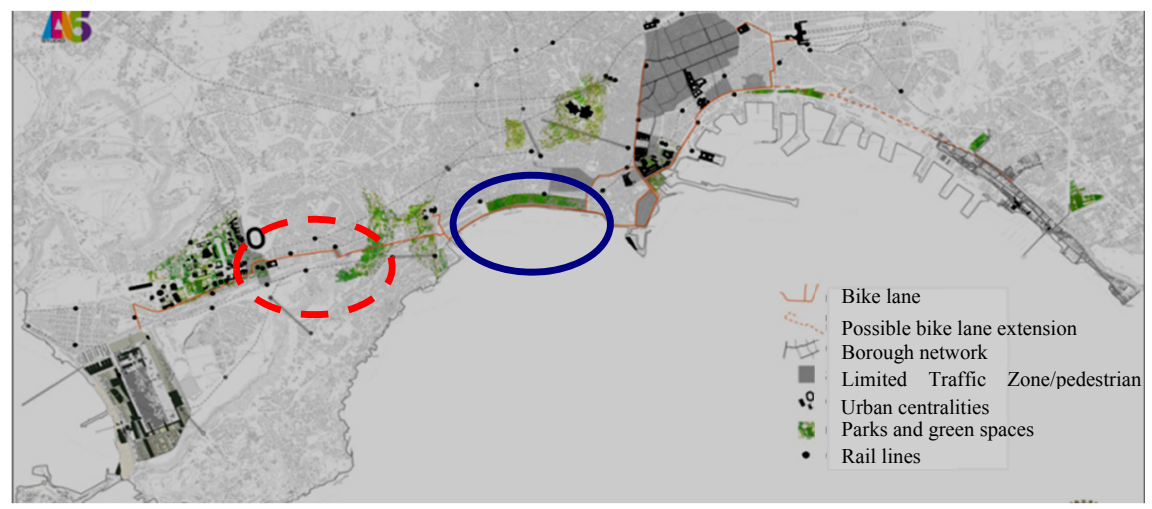

Figure 1: The bike lane in Naples.

However, this challenging project was accompanied by several problems connected with the real use of it. Indeed, the path of the bike lane is still full of obstacles, very curious and "funny" interruptions pushing cyclists to continue their travel on foot in the sections without lane: up to 37 interruptions deal with the Fuorigrotta, one of the boroughs where the lane passes through (highlighted with a dashed line circle in Fig. 1). Only in one point or two of the lane it is possible to travel 200/300 meters without interruptions. In the Italian regulation, the bike has priority on the car but the designers seemed to ignore it: stop signs are highly frequent on the driveway. Moreover the bike lane passes through a heavily polluted tunnel and its position is close only to the metro line 6 which is under construction and works no more than the morning.

Another disturbing feature is connected with the question of the maintenance, which retailers are complaining considering it totally inefficient, and the traffic control, since it happens that the lane is used by car for illegal parking.

The lane is built as a protected road for bikes only in the two circles in fig. 1 and in the gallery which is between the circles. In the other areas bike flow is mixed with pedestrian flow using pedestrian or restricted traffic zones or some sidewalks. Somewhere pedestrian flow is too dense for biking in safe.

\section{The survey}

A first survey was employed between the 27th and 28th December 2012; retailers and residents of the area directly affected by the bike lane in the borough of Fuorigrotta were interviewed to study the impact of the bike lane on the local economy. The choice of this borough was made because the bike lane has been built on one side of Augusto Street in Fuorigrotta and it has been protected by a band $20 \mathrm{~cm}$ high, removing car parking.

The questionnaire was made up to capture the effect of the increase/decrease of accessibility and its impact on the turnover relative to the several activities along Augusto Street and the subsequent reaction of the residents due to the reduction of parking places along the street where the bike lane had been built. 
Of the 100 questionnaires left to the activities, 61 were filled correctly.

In Table 2 the sample composition is reported:

Table 2: $\quad$ Sample characteristics.

\begin{tabular}{|l|l|}
\hline Activity (by the Italian Census) & No. of respondents \\
\hline Retail and repair shop (car and moto) & 2 \\
\hline Retail & 29 \\
\hline Hotels and restaurants & 14 \\
\hline Information and communication & 4 \\
\hline Professional, scientific and technical & 7 \\
\hline Residents & $\begin{array}{l}28 \text { (5 residents and 23 retailers who } \\
\text { are also residing in the area) }\end{array}$ \\
\hline Total & 61 \\
\hline
\end{tabular}

Very interesting are the data concerning the availability of parking spaces: before the intervention $87.88 \%$ of the retailers declared the difficulty of the potential consumers to park underlying the existence of the problem of the scarce parking places in the borough. After the intervention the little percentage of retailers, which didn't perceive a lack in parking spaces, became less than $1.5 \%$ $(12.12 \%$ of $12.12 \%)$. Such behavior is more evident for retailers residing in Fuorigrotta, who almost all complained about the lack of parking spaces after the intervention (see Table 3 for details).

Table 3: Availability of parking for potential customers.

\begin{tabular}{|l|r|r|r|r|}
\hline & \multicolumn{2}{|c|}{$\begin{array}{c}\text { Before } \\
\text { the bike lane }\end{array}$} & \multicolumn{2}{c|}{$\begin{array}{c}\text { If yes before, } \\
\text { after the bike lane }\end{array}$} \\
\hline & Yes & No & Yes & \multicolumn{1}{c|}{ No } \\
\hline Retailers & $12.12 \%$ & $87.88 \%$ & $87.88 \%$ & $12.12 \%$ \\
\hline $\begin{array}{l}\text { Retailers and } \\
\text { residents }\end{array}$ & $8.69 \%$ & $91.31 \%$ & $100 \%$ & $0 \%$ \\
\hline
\end{tabular}

From Table 4, it is possible to deduce the percentage decrease of turnover, for each economic category, due to the introduction of the bike lane. This estimation avoided to take into account the perception of the crisis since a specific question was asked to retailers. The average decrease was $25 \%$.

$90 \%$ of the respondents declared that their consumers did not use the bike to reach the activity. This result underlines the marginal role of the bike mode, whose use increased only a few with the introduction of the bike lane during the weekdays. To the question whether they thought that the bike lane could have been seriously considered as an alternative mode for home-delivering, $22.71 \%$ answered yes, but the real conditions of the lane were not fostering it. The remaining $77.29 \%$ totally disagreed with its use for such purpose. Another question which retailers disapproved concerned the freight delivering, which is now very difficult. 
Table 4: $\quad$ Percentage of turnover.

\begin{tabular}{|l|r|}
\hline \multicolumn{1}{|c|}{$\begin{array}{c}\text { Activity (defined by the Italian } \\
\text { Census) }\end{array}$} & Percentage \\
\hline $\begin{array}{l}\text { Car and motorbike retail and/or } \\
\text { reparation }\end{array}$ & -2.5 \\
\hline Retail (without car and motorbike) & -22.12 \\
\hline Hotels and restaurants & -34.09 \\
\hline Information and communication & -23.33 \\
\hline Professional, scientific and technical & -36.25 \\
\hline
\end{tabular}

The whole sample declared to have not been involved in the decision-making process and almost all the respondents was sure that if they had been involved in the decision to build the bike lane, a rational mobility plan would have been developed. It is a clear sign of the necessity of the consensus building to ensure the success of this transport measure.

A second survey was carried out between May and June 2013 in Caracciolo Street (highlighted with a line circle in Fig. 1) with the objective of evaluating the impacts of the bike lane on residents, on bike vendors, on bike repairing and selling shops. The sample was made up of 62 residents (95\% resident in Naples) and 5 shops renting bikes.

For the full sample (residents+shops), some criticisms on the bike lane arose (see Table 5). The uneven road surface and the perception of the danger connected with traffic flows represented the major criticisms ( $88 \%$ of the sample).

Table 5: Criticism on the bike lane (residents and shops).

\begin{tabular}{|l|l|l|}
\hline & Not influent & Influent \\
\hline Uneven road surface & $12 \%$ & $88 \%$ \\
\hline Lake of safe parking & $31 \%$ & $69 \%$ \\
\hline $\begin{array}{l}\text { Perceived danger from } \\
\text { road traffic }\end{array}$ & $12 \%$ & $88 \%$ \\
\hline
\end{tabular}

Residents that would consider the use of bike as a real alternative to car are $8.19 \%$ of the sample. The majority $(49.18 \%)$ are disappointed because of the question of low connection (see Table 6). Indeed the bike lane is the only safe bike route but its extension is marginal with respect to the road network. Thus people perceive unsafe conditions to reach the bike lane running into the car traffic flow. Moreover the bike lane is not achievable in some intersections due to the continuity of the protective band.

Concerning the work/study mobility, $38 \%$ of residents declared they would change their travel mode to bike if a well-connected and safe bike network will be realized. Table 7 shows the relevant impact on the mobility of a well-conceived bike network which induce people to a more sustainable mobility. The "bike" mode in the table includes also a replanned public transport in a multimodal approach which allows the bikers to carry bike on public transport without any cost charge $[8,9]$. 
Table 6: Use of the bike lane by residents.

\begin{tabular}{|l|r|}
\hline $\begin{array}{c}\text { Bike lane alternative to car } \\
\text { and motorbike }\end{array}$ & Percentage \\
\hline Yes & 8.19 \\
\hline Yes but risky & 26.23 \\
\hline $\begin{array}{l}\text { No, because it is not well } \\
\text { connected }\end{array}$ & 49.18 \\
\hline $\begin{array}{l}\text { No, because it doesn't cover } \\
\text { my trips }\end{array}$ & 6.55 \\
\hline No & 21.31 \\
\hline
\end{tabular}

Table 7: $\quad$ Preferred trip mode.

\begin{tabular}{|l|l|l|l|l|l|}
\hline Mode & Walking & Public & Motorbike & Car & Bike \\
\hline Nowadays & $10 \%$ & $18 \%$ & $17 \%$ & $48 \%$ & $8 \%$ \\
\hline Future & $1 \%$ & $8 \%$ & $14 \%$ & $31 \%$ & $46 \%$ \\
\hline
\end{tabular}

For vendors, an increase of the turnover has been registered of $+65 \%$ for bike selling shops and of $+80 \%$ for bike repairing shops.

\section{Conclusions}

It is well known that when the economic results of investments in various modes of transport are compared, cycle traffic seem to come out on top. The bicycle is a low cost mode of transport, for cyclists as well as for the society as a whole. In many cases, investments in bike mode infrastructures have led to greater revenues in terms of more tourists, better health conditions, travel cost savings and, not least, an increasing of the willingness to spend of the bike user which increase turnovers of the retailers close to bike infrastructures. But all such positive effects not always occur. The case study of the bike lane in Napoli is an example of bad policy of the local administration. Indeed the new bike lane has been built without any plan and it has been perceived by citizens as a sort of advertisement for the local administration. Thus the most evident result is the reduction of parking. Very few people use the bike lane and no effects has been registered on the car traffic congestion. Moreover, retailers whose shops are served by the bike lane declare a decrease of the turnover. However, they declared that better connection and a safer lane would have been supported by them proving the good perception that they have on a well-conceived cycling plan. Bike vendors and renters seem, on the other hand, to have benefited from this intervention.

\section{References}

[1] Forum for the Future, The engineer of the 21th century inquiry - Engineering for sustainability. Retrieved from www.forumforthefuture.org.uk, 2000. 
[2] Cascetta, E., Pagliara, F. \& Papola, A., Governance of urban mobility: complex systems and integrated policies, Advances in Complex Systems, 10, pp. 339-354, 2007.

[3] Cascetta, E. \& Pagliara, F., Integrated Railways-based Policies: The Regional Metro System project of Naples and Campania, Transport Policy, 2, pp. 81-93, 2008.

[4] Pagliara, F \& Papa, E., Urban rail systems investments: an analysis of the impacts on property values and residents' location, Journal of Transport Geography, 19, pp. 200-211, 2011.

[5] Clifton, K. J., Morrissey S \& Ritter C., Business cycles: catering to the bicycling market, TR news, 208, 23-32, 2012.

[6] Drennen E., Economic effects of traffic calming on urban small businesses, Report for the Department of Public Administration, San Francisco State University, 2003.

[7] Biggiero L., The impact of transport management on the local activity system: the role of limited traffic zones, WIT Urban Transport XX, 669, 2014.

[8] D’Acierno, L., Gallo, M., Biggiero, L. \& Montella, B., Replanning public transport services in the case of budget reductions. WIT Transactions on the Built Environment, 138, 2014.

[9] D'Acierno, L., Ciccarelli, R., Montella, B. \& Gallo, M., A multimodal multiuser approach for analysing pricing policies in urban contexts. Journal of Applied Sciences, 11(4), pp. 599-609, 2011.

[10] Clifton, K., Muhs, C., Morrissey, S., Examining Consumer Behavior and Travel Choices. Retrieved from http://www.otrec.us/project/411, 2013.

[11] Alliance for Biking and Walking, Biking and walking in the United States 2014 benchmarking report, The Library of Congress, 2014. 